\title{
Kolaborasi Otoritas Pajak Bersama Relawan Pajak Dalam Pemberian Layanan Perpajakan Di Kantor Pajak Pratama Jepara
}

Warno $^{1^{*}}$, Sanda Amalia F. ${ }^{1}$, Anisa Nurul Hidayah ${ }^{1}$, Arina Nurul Indah ${ }^{1}$, Wilda Yus'atika ${ }^{1}$, Nida Ulya Shofana ${ }^{1}$, Laela Azri Maulida ${ }^{1}$, Humaira Az Zahra ${ }^{1}$, Mir Atul Afifah ${ }^{1}$, Hilwa Septiani Aziza ${ }^{1}$, Saibatul Aslamiyah ${ }^{1}$

${ }^{1}$ Prodi Akuntansi Syariah, Fakultas Ekonomi dan Bisnis Islam, Universitas Islam Negeri Walisongo Semarang, Jl. Prof. Dr. Hamka No. 3 - 5, Semarang, Jawa Tengah

*Penulis koresponden: warno@walisongo.ac.id

\begin{tabular}{l} 
Info Artikel \\
\hline Riwayat: \\
Dikirim 20 Juli 2020 \\
Diterima 17 Agustus 2020 \\
Dipublikasi $31 \quad$ Agustus \\
2020
\end{tabular}

\section{Kata Kunci :}

Edukasi

EFIN

Pajak

Pelayanan

Relawan

\begin{abstract}
Abstrak
Kolaborasi otoritas pajak bersama mahasiswa yang selanjutnya disebut sebagai Relawan Pajak ini dilaksanakan di Kantor Pelayanan Pajak Pratama. Kegiatan Relawan Pajak merupakan salah satu bentuk pengabdian mahasiswa kepada masyarakat yang ditunjukkan melalui pelayanan, edukasi, dan sosialisasi perpajakan kepada Wajib Pajak yang datang ke KPP Pratama Jepara serta masyarakat umum dengan memanfaatkan teknologi informasi modern. Kegiatan Relawan Pajak ini juga bertujuan untuk mendukung penerimaan Surat Pemberitahuan Tahunan Wajib Pajak pada tahun 2020 serta meningkatkan kepatuhan Wajib Pajak. Pelayanan atau asistensi yang dilakukan Relawan Pajak diantaranya adalah mengarahkan wajib pajak yang datang sesuai dengan kebutuhan wajib pajak, membantu pengecekan nomor EFIN Wajib pajak, membantu Wajib Pajak mengisi laporan SPT serta mengedukasi Wajib Pajak proses pengisian SPT yang diharapkan agar pada tahun berikutnya Wajib Pajak dapat lapor mandiri tanpa perlu datang ke KPP Pratama Jepara.
\end{abstract}

\section{PENDAHULUAN}

Gaung reformasi perpajakan di Indonesia mulai terdengar pada tahun 1983 melalui peralihan sistem perpajakan yang paling mendasar, yaitu penggantian sistem official assesment menjadi sistem self assesment dan peluncuran lima paket undang-undang perpajakan. Berbeda dengan sistem perpajakan terdahulu yang didominasi oleh kewenangan fiskus, pada sistem perpajakan self assesment, Wajib Pajak berperan aktif dalam penghitungan, pembayaran, dan pelaporan pajak, sementara fiskus hanya berperan sebagai pengawas pelaksanaan perpajakan (Megarani, Warno, \& Fauzi, 2019).

Reformasi perpajakan tidak berhenti pada penggantian sistem perpajakan dan penerbitan undang-undang perpajakan. Reformasi dilanjutkan di ranah reformasi birokrasi, reformasi perpajakan jilid 1 dan jilid 2 hingga penerbitan undang-undang pengampunan pajak pada tahun 2016 (Awwaliyah, Agriyanto, \& Farida, 2019). Saat ini, Indonesia sedang melaksanakan reformasi perpajakan jilid 3 yang dimulai pada tahun 2017 setelah kebijakan pengampunan pajak dan direncanakan selesai pada tahun 2024 (Nabila, S, \& Manan, 2019). 


\section{Buletin Pembangunan Berkelanjutan}

Vol. 4 No. 2, Agustus 2020 hal. 45-55

Sasaran reformasi perpajakan dirumuskan dalam 5 pilar reformasi perpajakan, yaitu organisasi, sumber daya manusia, teknologi informasi dan basis data, proses bisnis, dan peraturan perundang-undangan. Kelima pilar tersebut juga menjadi sarana pemenuhan tujuan reformasi perpajakan untuk menjadikan Direktorat Jenderal Pajak sebagai institusi perpajakan yang kuat, kredibel, dan akuntabel. Oleh karena itu, reformasi perpajakan dilakukan secara menyeluruh melalui pembenahan administrasi perpajakan, perbaikan regulasi, dan peningkatan basis perpajakan.

Reformasi perpajakan jilid 3 fokus pada transformasi proses bisnis dan transformasi teknologi informasi. Direktorat Jenderal Pajak sebagai institusi pemerintah penghimpun penerimaan pajak negara merealisasikan transformasi melalui peluncuran program atau aplikasi perpajakan berbasis digital yang memberikan kemudahan pelayanan pada masyarakat sekaligus menyederhanakan alur pelayanan, sehingga keefektifan dan efisiensi pelayanan perpajakan meningkat.

E-Filing adalah layanan perpajakan berbasis teknologi informasi yang diluncurkan oleh Direktorat Jenderal Pajak untuk melayani pelaporan Surat Pemberitahuan (SPT) Tahunan secara elektronik yang dilakukan secara online dan realtime pada laman www.pajak.go.id. Penerapan E-Filing didukung oleh Peraturan Menteri Keuangan Nomor 9 Tahun 2018 tentang kewajiban penggunaan E-Filing. Peraturan ini berlaku mulai tanggal 1 April 2018 dan mewajibkan penggunaan E-Filing untuk melaporkan SPT PPh 21/26 dan PPN (Sustiyo \& Hidayat, 2019).

Peraturan Menteri Keuangan di atas berlaku untuk seluruh Wajib Pajak di Indonesia, sehingga seluruh kantor pelayanan pajak harus memberikan sosialisasi dan edukasi kepada Wajib Pajak yang bertempat tinggal di wilayah tempat kantor pelayanan pajak beroperasi, tak terkecuali Kantor Pelayanan Pajak (KPP) Pratama Jepara. KPP Pratama Jepara sebagai lembaga yang berada di bawah naungan Direktorat Jenderal Pajak berperan memberikan pelayanan, edukasi, dan sosialisasi perpajakan kepada para Wajib Pajak di Jepara.

Dikutip dari laman https://eprints.umk.ac.id, berdasarkan olah data dari KPP Pratama Jepara, diketahui bahwa pada tahun 2017 ada 83.875 Wajib Pajak orang pribadi yang terdaftar di KPP Pratama Jepara dan 74.729 diantaranya wajib melaporkan SPT Tahunan tetapi hanya ada 29.634 Wajib Pajak orang pribadi yang melaporkan pajak, baik secara manual atau melalui E-Filing. Namun pelaporan SPT Tahunan pribadi ditiadakan mulai tanggal 1 April 2018 menyusul diberlakukannya Peraturan Menteri Keuangan Nomor 9 Tahun 2018 tentang kewajiban penggunaan E-Filing.

Pada tahun 2019, portal berita https://radarkudus.jawapos.com memberitakan bahwa dua pekan sebelum batas waktu pelaporan SPT Tahunan, sebanyak 89,29 persen Wajib Pajak di Jepara sudah menyampaikan SPT Tahunan melalui E-Filing. Dilihat dari prosentasenya, penerapan E-Filing tampak efektif dan efisien tetapi kondisi di lapangan menunjukkan hal yang berbeda. Banyak Wajib Pajak yang belum mengerti cara pengisian E-Filing sehingga Wajib Pajak masih berondong-bondong datang ke kantor. Hal ini berlawanan dengan tujuan reformasi pajak bidang teknologi informasi dan basis data.

Penerapan E-Filing bagi Wajib Pajak di Jepara seharusnya dapat memudahkan Wajib Pajak sekaligus petugas pajak karena pengisian E-Filing bisa dilakukan di mana pun dan kapan pun tanpa harus datang ke KPP Pratama Jepara. Oleh karena itu, KPP Pratama Jepara gencar melakukan sosialisasi E-Filing kepada Wajib Pajak di Jepara dan memberi kesempatan kepada Relawan Pajak untuk ambil bagian dalam pelayanan, edukasi, dan sosialisasi perpajakan melalui asistensi pengisian SPT Wajib Pajak orang pribadi dengan E-Filing. 


\section{Buletin Pembangunan Berkelanjutan}

Vol. 4 No. 2, Agustus 2020 hal. 45-55

Kegiatan Relawan Pajak merupakan bentuk pengabdian masyarakat. Pengabdian ini ditunjukkan melalui pelayanan, edukasi, dan sosialisasi perpajakan kepada Wajib Pajak yang datang ke KPP Pratama Jepara serta masyarakat umum dengan memanfaatkan teknologi informasi modern. Selain itu, pengabdian ini bertujuan untuk mendukung penerimaan Surat Pemberitahuan Tahunan Wajib Pajak pada tahun 2020 serta meningkatkan kepatuhan Wajib Pajak di Jepara.

\section{Profil Kantor Pajak}

Berlokasi di Jalan Raya Ngabul Kilometer 9 Ngabul, Kecamatan Tahunan, Kabupaten Jepara 59428, Kantor Pelayanan Pajak (KPP) Pratama Jepara merupakan salah satu instansi di Direktorat Jenderal Pajak dan berada di bawah naungan Kementerian Keuangan yang dibentuk berdasarkan Surat Keputusan Menteri Keuangan Nomor: 55/PMK.01/2007 dan peresmian operasional kantor dilakukan di Yogyakarta pada tanggal 6 November 2007. KPP Pratama Jepara menempati gedung dua lantai milik Kementerian Keuangan Republik Indonesia.

Pendirian KPP Pratama Jepara dilatarbelakangi oleh peleburan tiga kantor pajak, yaitu Kantor Pelayanan Pajak, Kantor Pemeriksaan dan Penyidikan Pajak Karikpa, dan Kantor Pelayanan Pajak Bumi dan Bangunan. Ketiga kantor tersebut berada di bawah Kementerian Keuangan dan mewadahi penerimaan pajak di Kabupaten Demak, Kudus, dan Jepara. Peleburan ini dilakukan atas dasar reformasi perpajakan sebagai upaya pembentukan sistem perkantoran modern yang fokus pada satu wilayah kerja.

Kantor Pelayanan Pajak Pratama Jepara bertugas menghimpun penerimaan pajak di wilayah Jepara sekaligus memberikan pelayanan dan edukasi perpajakan kepada masyarakat Jepara, khususnya Wajib Pajak terdaftar. Selain itu, KPP Jepara juga memberikan pembinaan berupa konsultasi, penyuluhan, dan sosialisasi, serta berperan dalam pengawasan dan penegakan hukum kepada Wajib Pajak. Tidak hanya tatap muka, pelayanan juga dilakukan melalui pesawat telepon dengan nomor (0291) 596403, 596410, 596423 dan faximail dengan nomor (0291) 596342.

\section{METODE PELAKSANAAN}

Bentuk pengabdian masyarakat yang direalisasikan dalam program Relawan Pajak di Kantor Pelayanan Pajak (KPP) Pratama Jepara merupakan kerjasama antara Direktorat Jenderal Pajak Kanwil Jateng 1 bersama Tax Center UIN Walisongo Semarang. Dalam skala lebih luas, kegiatan serupa merupakan strategi dalam rangka edukasi perpajakan yang melibatkan peran Direktorat Jenderal Pajak dan Tax Center perguruan tinggi di seluruh Indonesia sebagai penggerak dan masyarakat sebagai target edukasi (Nusiantari \& Swasito, 2019).

Formasi Relawan Pajak di KPP Pratama Jepara diisi oleh mahasiswa yang lolos tahap rekruitmen dan seleksi yang diselenggarakan oleh Tax Center UIN Walisongo Semarang serta training bersama Relawan Pajak yang ditugaskan di KPP atau Kantor Pelayanan, Penyuluhan, dan Konsultasi Perpajakan (KP2KP) wilayah lain yang diselenggarakan oleh Direktorat Jenderal Pajak Kanwil Jateng 1. Sebelum berbaur dengan masyarakat, Relawan Pajak dibekali ilmu perpajakan sekaligus soft skill agar bisa adaptif dan komunikatif ketika berhadapan dengan masyarakat, khususnya Wajib Pajak dengan berbagai karakter dan latar belakang.

Usai training bersama, sebanyak 18 mahasiswa Prodi Akuntansi Syariah, 1 mahasiswa

Prodi Perbankan Syariah, dan 1 mahasiswa Prodi Ekonomi Islam UIN Walisongo Semarang resmi ditetapkan sebagai Relawan Pajak dengan tugas pengabdian di KPP Pratama Jepara. Selanjutnya, mahasiswa tersebut bertolak ke KPP Pratama Jepara pada tanggal 7 Februari 


\section{Buletin Pembangunan Berkelanjutan}

Vol. 4 No. 2, Agustus 2020 hal. 45-55

2020 untuk memperkenalkan diri, observasi sekaligus mendiskusikan perannya sebagi Relawan Pajak selama bertugas di KPP Pratama Jepara.

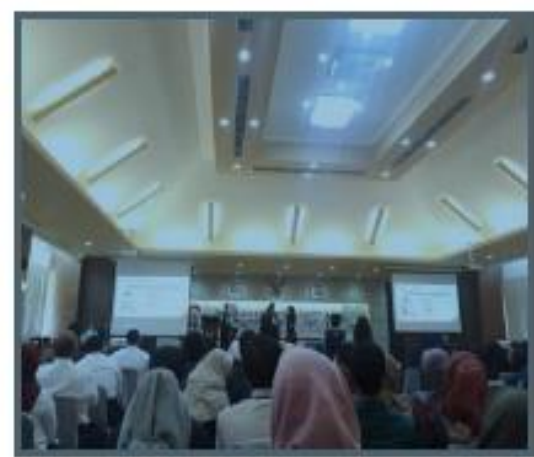

Gambar I

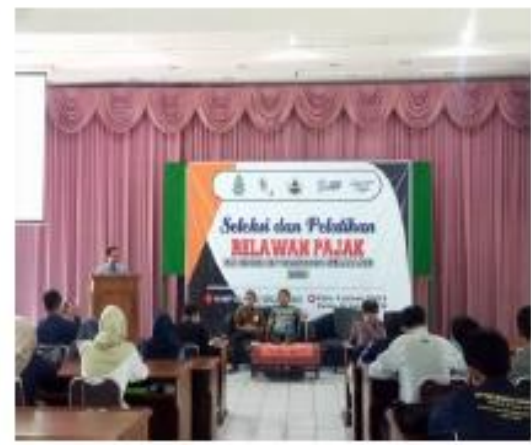

Gambar III

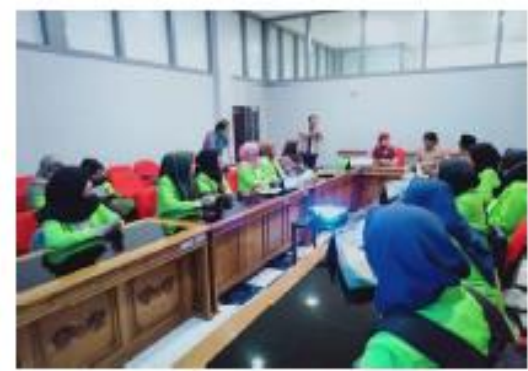

Gambar V

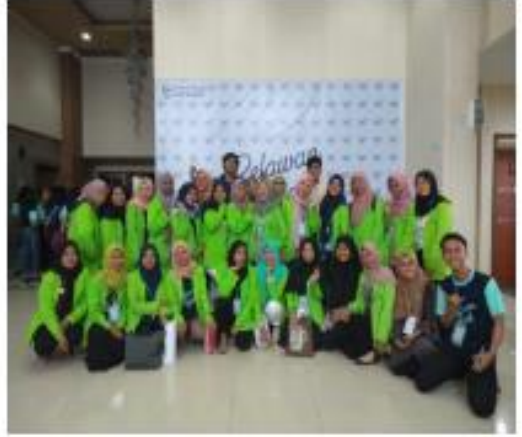

Gambar II

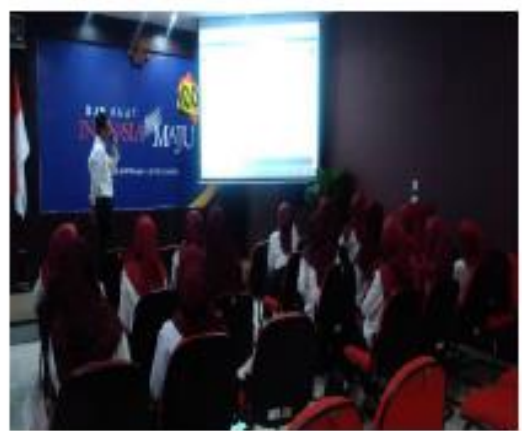

Gambar IV

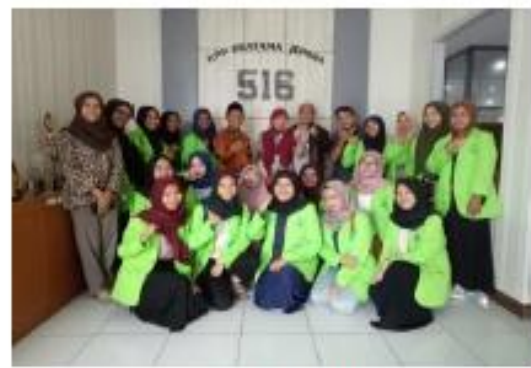

Gambar VI

Gambar 1. Gambar training relawan pajak

Kegiatan pengabdian sebagai Relawan Pajak di Kantor Pajak Pratama dijadwalkan berlangsung selama 1,5 bulan terhitung mulai tanggal 17 Februari sampai 31 Maret 2020. Selama itu pulalah Relawan Pajak dianggap sebagai representasi dari KPP Pratama Jepara sehingga Relawan Pajak diharapkan mampu menunjukkan komitmen, kompetensi, integritas, dan profesionalitasnya ketika berhadapan dengan Wajib Pajak. Relawan pajak tidak diperkenankan menerima imbalan dalam bentuk apapun.

Berdasarkan pertimbangan ketersediaan ruangan dan komputer, jam layanan Relawan Pajak dibagi menjadi 4 tim dengan 5 Relawan Pajak sebagai anggota setiap tim. Anggota tim diacak setiap minggu dan setiap tim bertugas secara bergantian dengan tim lain berdasarkan 


\section{Buletin Pembangunan Berkelanjutan}

Vol. 4 No. 2, Agustus 2020 hal. 45-55

jadwal hari dan shift yang dirilis setiap akhir pekan. Sederhananya, setiap hari ada 10 Relawan Pajak yang bertugas di KPP Pratama Jepara dengan rincian 5 Relawan Pajak bertugas saat shift pagi dan 5 Relawan Pajak bertugas saat shift siang.

Pengabdian kepada masyarakat ditunjukkan oleh Relawan Pajak melalui pemberian layanan, sosialisasi, dan asistensi pelaporan SPT Tahunan Wajib Pajak pribadi. Relawan pajak juga memberikan arahan pengisian SPT orang pribadi kepada Wajib Pajak yang kesulitan dalam mengisi laporan SPT tahunan dan memberikan jawaban atas beberapa pertayaan terkait perpajakan yang diajukan oleh Wajib Pajak. Dalam menjalakan tugasnya, Relawan Pajak didampingi oleh pegawai KPP Pratama Jepara agar tercipta sinergi dan transfer ilmu antar keduanya.

Berhubung kegiatan pengabdian di KPP Pratama Jepara difokuskan pada asistensi pengisian SPT Tahunan Wajib Pajak pribadi dengan E-Filing, Relawan Pajak diharapkan mampu menyesuaikan diri saat berkomunikasi dengan Wajib Pajak yang memiliki karakter serta latar belakang berbeda-beda. Menanggapi hal tersebut, Relawan Pajak menerapkan tiga metode pengabdian, yaitu observasi dan wawancara serta pelatihan dan pendampingan. Kedua metode ini secara aktif melibatkan peran Wajib Pajak.

Pada tahap observasi dan wawancara, Relawan Pajak memberikan beberapa pertanyaan kepada Wajib Pajak untuk memperoleh gambaran umum kondisi Wajib Pajak. Berdasarkan hasil observasi dan wawancara, kebanyakan Wajib Pajak mengeluhkan ketidaktahuannya atas pelaporan SPT Tahunan dengan E-Filing serta beberapa keluhan lain seputar pelaporan SPT. Selanjutnya, Relawan Pajak menyesuaikan pemberian treatment dengan permasalahan yang dikeluhkan Wajib Pajak.

Tahap pelatihan dan pendampingan merupakan tindak lanjut dari hasil observasi dan wawancara. Misalnya, Wajib Pajak yang mengeluhkan E-Filing akan diberikan pelatihan pengisian E-Filing sekaligus di dampingi dalam pengisiannya. Artinya, Relawan Pajak hanya sebagai fasilitator dan Wajib Pajaklah yang berperan aktif dalam pengoperasian E-Filing. Hal ini dimaksudkan untuk membentuk kemandirian Wajib Pajak, sehingga tahun depan Wajib Pajak mampu mengisi E-Filing secara mandiri tanpa datang ke KPP Pratama Jepara.

\section{HASIL DAN PEMBAHASAN}

Relawan Pajak adalah program kerjasama antara otoritas pajak dan lembaga pendidikan tinggi sebagai wujud edukasi dan sosialisasi perpajakan, khususnya pengisisan Surat Pemberitahuan Tahunan (SPT) secara online. UIN Walisongo sebagai salah satu lembaga pendidikan tinggi ikut andil dalam program ini. Salah satunya diwujudkan dengan menerjunkan 20 mahasiswa sebagai Relawan Pajak 2020 dengan tugas pengabdian di Kantor Pelayanan Pajak (KPP) Pratama Jepara (Putri \& Agustin, 2018).

Pelaksanaan program Relawan Pajak 2020 di KPP Pratama Jepara semula direncanakan berlangsung pada 17 Februari - 31 Maret 2020 (6 minggu) namun hanya terlaksana empat minggu, yaitu pada 17 Februari s.d 13 Maret 2020. Dua minggu yang urung dilaksanakan akibat dari pembekuan kegiatan Relawan Pajak 2020 untuk mencegah penyebaran Covid-19 (Annapisa, 2018).

Bagi para mahasiswa yang ditempatkan di KPP Pratama Jepara, menjadi Relawan Pajak merupakan bentuk pengabdian kepada masyarakat. Pengabdian ini ditunjukkan melalui edukasi dan sosialisai perpajakan kepada para Wajib Pajak yang datang ke KPP Pratama Jepara. Konkritnya, Relawan Pajak memberikan asistensi pengisan SPT Wajib Pajak orang pribadi dengan E-Filing dan memberikan bantuan di bagian pelayanan Wajib Pajak. 


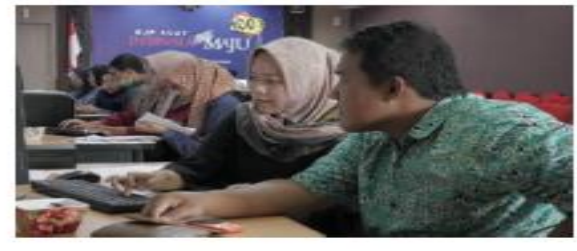

Gambar $V I I$

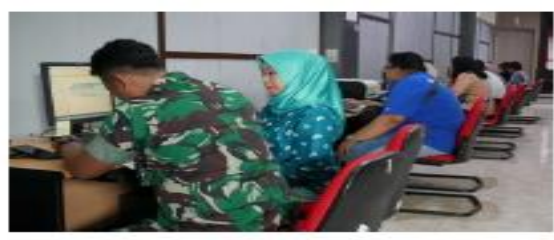

Gambar $I X$

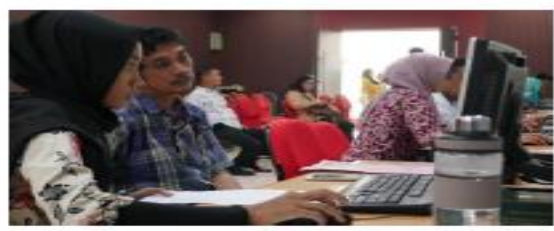

Gambar XZ

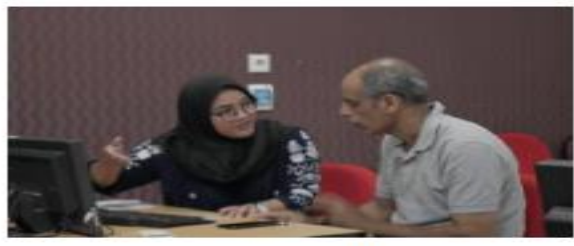

Gambar VIII

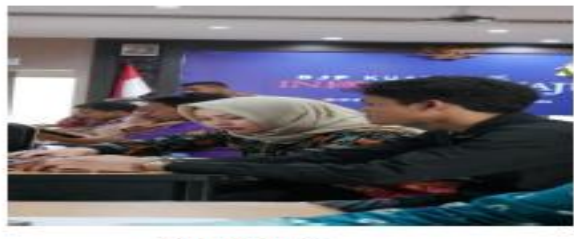

Gambar $X$

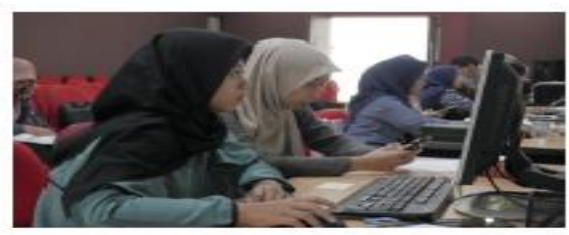

Gambar XZI

Gambar 2. Pelaksanaan asistensi pengisian SPT

1. Asistensi pelaporan SPT Tahunan Wajib Pajak dengan E-Filing

Direktorat Jederal Pajak (DJP) telah mengembangkan sistem pelaporan pajak berbasis online. Pada tahun 2014, DJP menyatukan semua layanan pelaporan di bawah satu sistem dan membuat situs DJP Online sebagai pusat pelayanan SPT elektronik. Situs DJP Online dengan alamat website http://djponline.pajak.go.id dapat diakses melalui seluruh perangkat yang memiliki jaringan internet.

Kantor Pelayanan Pajak (KPP) Pratama Jepara sebagai lembaga yang berada di bawah naungan DJP berperan memberikan pelayanan, edukasi, dan sosialisasi perpajakan kepada para Wajib Pajak di Jepara. Oleh karena itu, KPP Pratama Jepara memberi kesempatan kepada Relawan Pajak untuk ambil bagian dalam pelayanan, edukasi, dan sosialisasi perpajakan melalui asistensi pengisian SPT Wajib Pajak orang pribadi dengan E-Filing (Syawaldi \& Hastuti, 2020).

Relawan Pajak yang memberikan asistensi pelaporan SPT dengan E-Filing tidak hanya membantu mengisikan SPT, namun juga memberikan penjelasan proses pengisiannya sehingga tahun depan Wajib Pajak bisa lapor mandiri tanpa datang ke KPP Pratama Jepara. Hal ini sejalan dengan tujuan reformasi pajak dalam bidang teknologi informasi dan basis data.

Perbedaan jumlah asistensi disebabkan oleh durasi pelayanan kepada setiap Wajib Pajak. Latar belakang Wajib Pajak yang berbeda-beda membawa permasalahan yang berbeda pula sehingga perlakuannya pun berbeda. Relawan Pajak harus bisa menjelaskan dengan bahasa yang mudah dipahami Wajib Pajak sehingga tahun depan Wajib Pajak mampu melaporkan SPT dengan E-Filing secara mandiri. 
Tabel 1. Asistensi relawan pajak 2020 di KPP Pratama Jepara

\begin{tabular}{lcc}
\hline Nama Relawan Pajak & $\begin{array}{c}\text { Jumlah } \\
\text { Asistensi* }\end{array}$ & Keterangan \\
\hline Eva Nurul Anisa & 25 & Koordinator \\
Adibatur Rahmawati & 32 & Asistensi \\
Anisa Nurul Hidayah & 28 & Asistensi \\
Arina Nurul Indah & 31 & Asistensi \\
Dea Feby Septiani & 50 & Asistensi \\
Elisa Martha Hanum B & 40 & Asistensi \\
Hilwa Septiani Aziza & 66 & Asistensi \\
Humaira Azzahra & 32 & Asistensi \\
Isna Nur Janah & 25 & Asistensi \\
Laela Azri Maulida & 25 & Asistensi \\
Mir Atul Afifah & 38 & Asistensi \\
Nanda Rizka Amalia & 35 & Asistensi \\
Nida Ulya Shofana & 35 & Asistensi \\
Nina Nuraina & 50 & Asistensi \\
Nur Laeli Maghfiroh & 30 & Asistensi \\
Riza Muizzah Asri & 24 & Asistensi \\
Saibatul Aslamiyah & 56 & Asistensi \\
Sanda Amalia F & 32 & Asistensi \\
Tri Ananda Mei Saputri & 40 & Asistensi \\
Wilda Yus'atika & 35 & Asistensi \\
\hline
\end{tabular}

*dihitung berdasarkan Surat Pernyataan Ketersediaan Wajib Pajak Menerima Asistensi dari Relawan Pajak yang dikumpulkan oleh Relawan Pajak selama bertugas dan ditandatangani oleh Wajib Pajak

2. Bantuan bagian pelayanan Wajib Pajak

Seiring waktu berlalu, Relawan Pajak juga membantu bagian pelayanan Wajib Pajak di Kantor Pelayanan Pajak (KPP) Pratama Jepara. Pertama, Relawan Pajak membantu mengarahkan Wajib Pajak yang datang ke KPP Pratama Jepara menuju ke bagian tertentu sesuai kebutuhan Wajib Pajak. Kedua, Relawan Pajak membantu pengecekan nomor EFIN Wajib Pajak. Ketiga, Relawan Pajak membantu secara kondisional bagian pelayanan Wajib Pajak.

Pelayanan Wajib Pajak oleh Relawan Pajak tidak hanya terjadi saat di kantor saja, melainkan bisa terjadi di luar kantor dengan memanfaatkan teknologi informasi. Relawan Pajak aktif meanfaatkan media sosial untuk mempublikasikan tata cara pengisian SPT secara mandiri dan online. Publikasi semacam ini dapat menjangkau Wajib Pajak di luar Kabupaten Jepara sehingga Relawan Pajak dapat mendukung tercapainya reformasi pajak di bidang teknologi informasi dan basis data.

Komitmen reformasi perpajakan di bidang teknologi informasi dan basis data melahirkan inovasi baru berupa Kring Pajak dengan nomor kontak 1500200. Kring pajak adalah layanan berupa call center yang dibentuk oleh Direktorat Jenderal Pajak untuk meningkatkan mutu pelayanan dan keterbukaan dalam informasi perpajakan untuk Wajib Pajak,baik perorangan maupun badan yang telah diatur dalam peraturan ditjen pajak No: PER02/PJ/2014 dan PER-22/PJ/2014.

Ragam layanan yang bisa masyarakat gunakan saat menggunakan Kring Pajak diantaranya bertanya soal SPT Tahunan,pajak penghasilan,kurang bayar,macam-macam 


\section{Buletin Pembangunan Berkelanjutan}

Vol. 4 No. 2, Agustus 2020 hal. 45-55

pengaduan pungutan liar, alur pembayaran atau melaporkan pajak dan beberapa konsultasi yang dapat melalui kring pajak antara lain: cara menggunakan aplikasi elektronik DJP, EFilling, E-SPT, E-Billing, dan aplikasi lainnya.

Khusus Wajib Pajak di Kabupaten Jepara, KPP Pratama Jepara menyediakan nomor khusus pelayanan Wajib Pajak. Wajib Pajak dapat berinteraksi denagan Petugas Pajak di KPP Pratama Jepara melalui aplikasi whatsaap dengan nomor 082137447820 untuk pendaftaran NPWP dan permohonan PKP, 0811516506 untuk kode Billing, serta nomor telepon 0291596403 untuk layanan EFIN, pengajuan permohonan, dan sertifikat elektronik.

Berbagai fitur layanan Wajib Pajak di atas dikembangkan berdasarkan perkembangan teknologi informasi dan basis data. Sistem online terbukti mampu menyederhanakan alur dan sistem perpajakan karena fleksibilitasnya. Manfaat tersebut semakin terasa saat KPP Pratama Jepara harus menutup pelayanan tatap muka sebagai dampak dari pandemi covid-19. Layanan pajak tetap berlangsung sehingga Wajib Pajak mampu memenuhi kewajiban perpajakannya.

Program Relawan Pajak merupakan kegiatan pengabdian masyarakat yang direalisasikan melalui asistensi pengisian SPT Tahunan Wajib Pajak pribadi serta sosialisasi perpajakan. Formasi Relawan Pajak diisi oleh para mahasiswa yang lolos tahap rekruitmen dan seleksi dari Tax Center Perguruan Tinggi sebagai wakil dari DJP Kanwil Jateng 1. Selanjutnya, mahasiswa yang dinyatakan lolos tahap rekruitmen dan seleksi mengikuti training bersama di DJP Kanwil Jateng 1 untuk menambah ilmu perpajakan, mengasah softskill komunikasi, serta public speaking (Handayani \& Noviari, 2016).

Saat training bersama, Relawan Pajak menandatangani surat pernyataan berupa kesanggupan memamatuhi code of conduct selama pengabdian kepada masyarakat. Code of conduct adalah pedoman perilaku atau kode etik yang mengikat Relawan Pajak secara mutlak. Pedoman ini dibuat untuk mendisiplinkan Relawan Pajak sekaligus menciptakan pola hubungan yang harmonis antara Otoritas Pajak, Relawan Pajak, dan Wajib Pajak,

Berdasarkan rekruitmen, seleksi, dan training di atas, sebanyak 20 Relawan Pajak mendapat tugas pengabdian di Kantor Pelayanan Pajak (KPP) Pratama Jepara. Keberadaan Relawan Pajak dimaksudkan untuk membantu pegawai kantor pajak dalam melayani pelaporan SPT Tahunan Wajib Pajak saat memasuki waktu pelaporan yang dimulai pada bulan Januari sampai Maret. Selain itu, Relawan Pajak berkomitmen membantu pemerintah dalam meningkatkan kepatuhan Wajib Pajak dalam penghitungan, peaporan, dan pembayaran pajak.

Relawan Pajak yang ditempatkan di KPP Pratama Jepara dikonsentrasikan untuk memberikan asistensi pelaporan SPT Tahunan Wajib Pajak pribadi melalui E-Filing dengan form SPT 1770S atau SPT 1770SS. Selain itu, Relawan Pajak membantu bagian pelayanan di KPP Pratama Jepara untuk mengarahkan Wajib Pajak menuju bagian tertentu sesuai kebutuhan Wajib Pajak, serta mencetak dan memeriksa EFIN.

1. Asistensi pelaporan SPT Tahunan Wajib Pajak dengan E-Filing

Surat Pemberitahuan (SPT) adalah laporan pajak yang disampaikan kepada pemerintah Indonesia melalui Direktorat Jenderal Pajak. Ketentuan mengenai SPT diatur dalam Undang-Undang Nomor 28 Tahun 2007 tentang Ketentuan Umum dan Tata Cara Perpajakan. Dalam undang-undang tersebut ditegaskan bahwa pemerintah mengharuskan seluruh Wajib Pajak untuk melaporkan SPT sesuai dengan ketentuan yang berlaku.

Surat Pemberitahuan (SPT) pajak memiliki tiga fungsi pelaporan. Pertama, melaporkan pelunasan atau pembayaran pajak yang sudah dilakukan, baik secara personal maupun melalui pemotongan penghasilan dari perusahaan dalam jangka waktu satu tahun. Kedua, melaporkan harta benda yang dimiliki di luar penghasilan tetap dari pekerjaan utama. Ketiga, melaporkan penghasilan lainnya yang termasuk ke dalam kategori objek pajak maupun bukan objek pajak. 


\section{Buletin Pembangunan Berkelanjutan}

Vol. 4 No. 2, Agustus 2020 hal. 45-55

Wajib Pajak adalah setiap orang yang terlibat dalam aktivitas perpajakan termasuk pembayar pajak, pemotong pajak, dan pemungut pajak. Karena disebut sebagai Wajib Pajak, seseorang memiliki hak dan kewajiban yang harus dipenuhi. Hak dan kewajiban inilah yang dilindungi oleh pemerintah melalui undang-undang.

Kewajiban Wajib Pajak antara lain memiliki NPWP, membayar, memotong, dan melaporkan pajak, kooperatif pada saat mengikuti pemeriksaan pajak. Disamping itu, Wajib Pajak memiliki hak atas kelebihan pembayaran pajak, hak untuk dijaga kerahasiaan identitanya, hak untuk mengangsur dan menunda pembayaran dengan melaporkan alasannya serta hak untuk dibebaskan dari kewajiban perpajakan (Tamboto, 2013).

Sehubungan dengan penjelasan di atas, asistensi pelaporan SPT adalah kegiatan yang dilakukan oleh Relawan Pajak untuk membantu Wajib Pajak yang akan melakukan pelaporan SPT di KPP Pratama Jepara. Bantuan yang diberikan relawan pajak berupa penjelasan singkat mengenai pendampingan dan pelatihan pelaporan SPT Tahunan Wajib Pajak pribadi dengan E-Filing. Tambahannya, Wajib Pajak diperkenankan berkonsultasi dengan Relawan Pajak terkait pelaporan SPT Tahunan.

Asistensi peaporan SPT Tahunan kepada Wajib Pajak diharapkan mampu menambah pemahaman Wajib Pajak terhadap pelaporan SPT Tahunan melalui E-Filing, sehingga Wajib Pajak dapat melaporkan SPT Tahunan secara mandiri tanpa datang ke KPP Pratama Jepara. Hal ini sejalan dengan reformasi perpajakan bidang teknologi informasi dan basis data. Selain itu, partisipasi aktif Wajib Pajak dalam pelaporan SPT Tahunan dapat meningkatkan kepatuhan Wajib Pajak dalam memenuhi kewajiban perpajakannya.

Bertugas sebagai Relawan Pajak di KPP Pratama Jepara dituntut untuk adaptif dan komunikatif karena Kabupaten Jepara memiliki penduduk dengan latar belakang pendidikan, ekonomi, dan profesi yang berbeda-beda, sehingga karakternya pun berbeda. Perbedaan tersebut memicu beberapa kendala dalam pemberian asistensi kepada Wajib Pajak. Kebanyakan kendala berasal dari human error atau kesalahan manusia.

Pertama, Wajib Pajak tidak mengingat password akun E-Filing, Wajib Pajak melupakan e-mail yang terdaftar di akun E-Filing, dan/atau Wajib Pajak tidak mengingat keduanya padahal sudah pernah menggunakan E-Filing untuk melaporkan SPT Tahunan pada tahun lalu. Kendala seperti ini dialami oleh Wajib Pajak yang sudah sepuh dan memiliki keterbatasan dalam memahami tekonologi.

Solusi untuk permasalahan di atas adalah Relawan Pajak membantu Wajib Pajak untuk mengganti password E-Filing melalui e-mail yang tertaut dengan akun E-Filing Wajib Pajak. Pada kasus Wajib Pajak lupa password dan e-mail, maka Relawan Pajak membantu Wajib Pajak untuk membuat e-mail dan password yang baru. Selanjutnya, Relawan Pajak memberikan rekap informasi dalam selembar kertas dan berpesan kepada Wajib Pajak untuk menyimpannya karena berguna dalam pelaporan SPT Tahun depan (Lingga, 2013).

Kedua, Kesalahan pada bukti potong yang dibawa oleh Wajib Pajak. Ada beberapa Wajib Pajak yang bukti potongnya terdapat salah hitung, seperti jumlah PTKP yang belum diupdate, padahal waib pajak memiliki tambahan tanggungan. Ada juga kesalahan penghitungan jumlah pajak yang harus dibayarkan oleh Wajib Pajak. Jika masalahnya seperti itu, Relawan Pajak akan berkonsultasi dengan pegawai kantor pajak sebelum memberikan treatment kepada Wajib Pajak.

Ketiga, banyak WNA yang bekerja di Jepara dan tidak bisa berbahasa Indonesia atau Inggris. Perbedaan bahasa cenderung menghambat proses asistensi karena keterbatasan lomunikasi. Dalam situasi seperti itu, Relawan Pajak akan menjelaskan proses pengisian E- 
Filing secara perlahan dengan memanfaatkan dokumen yang dibawa Wajib Pajak. Tak lupa, Relawan Pajak memberitahukan kondisi ini kepada pegawai yang sedang bertugas.

2. Bantuan bagian pelayanan Wajib Pajak

Kesibukan KPP Pratama Jepara meningkat saat bulan Maret. Mempertimbangkan kesibukan kantor dan jumlah pegawai yang terbatas, KPP Pratama Jepara menugaskan 4 Relawan Pajak untuk membantu bagian pelayanan Wajib Pajak secara bergantian pada shift pagi dan siang. Di samping itu, ada 10 Relawan Pajak yang bertugas memberikan asistensi pelaporan SPT Tahunan melalui E-Filing kepada Wajib Pajak. Tugas asistensi ini pun dilakukan secara bergantian berdasarkan ketentuan jadwal hari dan shift.

Relawan Pajak yang membantu memeriksa kelengkapan persyaratan pelaporan SPT Tahunan Wajib Pajak. Selain itu, Relawan Pajak memberikan nomor antrian kepada Wajib Pajak agar tertib. Jika syarat yang dibutuhkan sudah lengkap, termasuk nomor EFIN untuk mengakses akun E-Filing, Wajib Pajak akan iberikan nomor antrian untuk pelaporan SPT. Tetapi ketika Wajib Pajak belum mengetahui nomor EFIN ataupun lupa password akun EFiling, akan diberikan nomor antrian untuk mencetak nomor EFIN baru setelah itu diberikan nomor antrian untuk pelaporan SPT.

Electronic Filing Identification Number (EFIN) adalah nomor identitas yang diterbitkan oleh Direktorat Jenderal Pajak kepada Wajib Pajak yang melakukan transaksi elektronik dengan Ditjen Pajak, seperti laporan SPT melalui E-Filing dan pembuatan kode biliing untuk pembayaran pajak. Khusus Wajib Pajak di Jepara dapat menghubungi nomor telepon 0291596403 untuk konsultasi layanan EFIN dengan KPP Pratama Jepara (Suherman, Medina, \& Marliana, 2015).

\section{KESIMPULAN}

Relawan Pajak merupakan salah satu bentuk Inklusi Kesadaran Pajak yang merupakan kerja sama antara Otoritas Pajak dengan Lembaga Pendidikan Tinggi. Kegiatan relawan pajak berisi kegiatan pengabdian kepada masyarakat untuk membantu pelaporan SPT tahunan Wajib Pajak pribadi melalui E-Filing. Kegiatan ini bertujuan untuk mendukung penerimaan SPT Tahunan setiap tahunnya, dan meningkatkan kepatuhan Wajib Pajak.

\section{UCAPAN TERIMA KASIH}

Terima kasih kepada KPP Pratama Jepara dan Kanwil DJP Jateng serta Prodi Akuntansi Syariah UIN Walisongo Semarang yang telah memberikan dukungan kerjasama sehingga terselenggaranya kegiatan ini

\section{DAFTAR PUSTAKA}

Annapisa, M. (2018). Peran Media Cetak Lokal dalam Komunikasi Bencana sebagai Pendukung Manajemen Bencana. Buletin Pembangunan Berkelanjutan, 2(1), 102-115.

Awwaliyah, N. F., Agriyanto, R., \& Farida, D. N. (2019). The effect of regional original income and balance funding on regional government financial performance. Journal of Islamic Accounting and Finance Research, 1(1), 25. https://doi.org/10.21580/jiafr.2019.1.1.3745

Handayani, M., \& Noviari, N. (2016). Pengaruh Persepsi Manajemen Atas Keunggulan Penerapan E-Billing Dan E-Spt Pajak Pertambahan Nilai Pada Kepatuhan Perpajakan. EJurnal Akuntansi, 15(2), 1007-1-1028.

Lingga, I. salsalina. (2013). Pengaruh Penerapan e-SPT Terhadap Kepatuhan Pajak: Studi Empiris Terhadap Pengusaha Kena Pajak di Wilayah KPP Pratama "X" Jawa Barat I Ita Salsalina Lingga. Jurnal Akuntansi, 5(1), 50-60.

Megarani, N., Warno, W., \& Fauzi, M. (2019). The effect of tax planning, company value, and leverage on income smoothing practices in companies listed on Jakarta Islamic Index. Journal of Islamic Accounting and Finance Research, 1(1), 139. 


\section{Buletin Pembangunan Berkelanjutan}

Vol. 4 No. 2, Agustus 2020 hal. 45-55

https://doi.org/10.21580/jiafr.2019.1.1.3733

Nabila, D. T. Della, S, I. D. K. Y., \& Manan, A. (2019). Edukasi Penggunaan E-Filing Melalui Program Relawan Pajak 2019, 1(2), 217-222.

Nusiantari, D., \& Swasito, A. P. (2019). Peran Penerimaan Pajak Dalam Usaha Pemerataan Pendapatan. Jurnal Pajak Indonesia, 3(1), 35-41.

Putri, \& Agustin, D. (2018). Pengaruh Pengetahuan Perpajakan Dan Sanksi Pajak Terhadap Kepatuhan Wajib Pajak Orang Pribadi (Studi Kasus: Kpp Pratama Kebayoran Lama Kota Jakarta Selatan). Media Akuntansi Perpajakan, 3(2), 1-9.

Suherman, M., Medina, A., \& Marliana, R. (2015). Pengaruh Penerapan E-Filing Terhadap Kepatuhan Wajib Pajak Dalam Penyampaian Surat Pemberitahuan ( Spt ) Tahunan Pada Kantor Pelayanan Pajak Pratama. Media Riset Akuntansi, Auditing \& Informasi, 15(1), 4964.

Sustiyo, J., \& Hidayat, T. R. (2019). Literasi keuangan dan pajak pertambahan nilai (PPN) pada generasi z. Jurnal Pajak Indonesia, 3(3), 24-34.

Syawaldi, \& Hastuti, K. (2020). Penyuluhan Ilmu Pengetahuan dan Teknologi Tepat Guna Dalam Meningkatkan Ekonomi Desa di Kabupaten Kepulauan Meranti. Buletin Pembangunan Berkelanjutan, 4(1), 22-27. https://doi.org/10.25299/bpb.2020.5029

Tamboto, F. (2013). Pengaruh Penerapan E-Spt Ppn Terhadap Efisiensi Pengisian Spt Ppn Menurut Persepsi Pengusaha Kena Pajak Pada Kpp Pratama Manado. Jurnal Riset Ekonomi, Manajemen, Bisnis Dan Akuntansi, 1(4), 2059-2068. https://doi.org/10.35794/emba.v1i4.3415 